REFLEKSI EDUKATIKA : Jurnal Ilmiah Kependidikan

Volume 9 Nomor 2 Juni 2019

ISSN: 2087-9385 (print) dan 2528-696X (online) http://jurnal.umk.ac.id/index.php/RE

\title{
LITERASI INFORMASI GURU PENDIDIKAN AGAMA BUDDHA DAN IMPLIKASINYA DALAM PEMBELAJARAN
}

\section{Suntoro}

Sekolah Tinggi Agama Buddha Negeri Sriwijaya Tangerang

Email: suntoro@stabn-sriwijaya.ac.id

\section{Info Artikel Abstract}

Sejarah Artikel:

Diterima 13 Maret 2019

Direvisi 31 Mei 2019

Disetujui 1 Juni 2019

Keywords:

literacy, information literacy, teacher of Buddhism

This study aims to describe the information literacy of Buddhist Education teachers in Pati Regency covering aspects of information needs, access to information, and utilization of information in teaching. This study uses a qualitative method. The data collection technique of this study uses interviews, observation, and documentation. Data analysis using the Milles \& Hubberman model includes the stages of data collection, data reduction, data presentation, and drawing conclusions. The results of this study include: (1)The information needs of Buddhist Education teachers can be classified into information needs to improve teacher competence and information needs for career advancement; (2) access to information sourced from various locations, the teachers have also been able to analyze, organize, and save information well; (3) the teacher utilizes the information literacy results in teaching and learning activities in the school despite experiencing obstacles such as the lack of infrastructure to support learning.

\begin{abstract}
Abstrak
Penelitian ini bertujuan untuk mendeskripsikan literasi informasi guru Pendidikan Agama Buddha (PAB) di Kabupaten Pati mencakup aspek kebutuhan informasi, akses informasi, dan pemanfaatan informasi dalam pengajaran. Penelitian ini menggunakan metode kualitatif. Teknik pengumpulan data penelitian ini menggunakan wawancara, observasi, dan dokumentasi. Analisis data menggunakan model Milles \& Hubberman mencakup tahapan pengumpulan data, reduksi data, penyajian data, dan penarikan simpulan. Hasil penelitian ini antara lain: (1) kebutuhan informasi guru PAB di Kabupaten Pati secara umum dapat diklasifikasikan menjadi kebutuhan informasi untuk peningkatan kompetensi guru dan kebutuhan informasi untuk peningkatan karier; (2) akses informasi bersumber dari berbagai lokasi, para guru juga telah mampu menganalisis, mengorganisasi, dan menyimpan perolehan informasi dengan baik; (3) guru memanfaatkan hasil literasi informasi dalam kegiatan belajar mengajar di sekolah meskipun mengalami kendala seperti minimnya sarana prasarana penunjang pembelajaran.
\end{abstract}

(C) 2019 Universitas Muria Kudus 
Suntoro, S.

LITERASI INFORMASI GURU PENDIDIKAN AGAMA BUDDHA DAN IMPLIKASINYA ... REFLEKSI EDUKATIKA : Jurnal Ilmiah Kependidikan, Volume 9, Nomor 2, Juni 2019, hlm 182-191

\section{PENDAHULUAN}

Berbicara tentang guru adalah berbicara tentang masa depan bangsa, termasuk Indonesia. Di ruang kelasnya ada wajah masa depan sebuah negara. Kita boleh terus mencari format kurikulum, namun kurikulum tanpa guru yang berkualitas nyaris tak ada artinya. Guru memegang peran yang sangat vital, mendasar, jangka panjang, dan mahal bagi suatu bangsa. Oleh karena itu, dibutuhkan guru-guru yang berkualitas, inspiratif, dan mendidik dengan hati.

Mengingat peran guru yang sangat vital sebagai ujung tombak keberhasilan pendidikan suatu bangsa, guru dituntut profesional dalam menjalankan tugas mengajarnya. Guru harus memiliki seperangkat pengetahuan, keterampilan, dan perilaku yang harus dimiliki, dihayati, dan dikuasai dalam melaksanakan tugas keprofesionalan. Menurut penjelasan Peraturan Pemerintah No 19 tahun 2005 tentang Standar Nasional Pendidikan, seorang guru harus memiliki empat kompetensi yang disyaratkan. Kompetensi itu adalah kompetensi paedagogik, sosial, kepribadian, dan profesional. Selain prima dalam tugas mengajar, seorang guru dituntut memilik pribadi yang baik dan jiwa sosial yang tanggap.

Oleh karena itu, penting bagi guru membudayakan literasi informasi untuk menunjang kompetensi sebagai tenaga pendidik profesional. Guru dituntut untuk terus mengembangkan diri agar dapat mengikuti perkembangan dan tuntutan dunia pendidikan dengan cara mengakses informasi secara terusmenerus. Perkembangan teknologi informasi di satu sisi memudahkan guru untuk mengembangkan kompetensi yang dimiliki. Di sisi lain kemudahan akses informasi bisa jadi tidak memberikan pengaruh jika tidak disikapi secara bijak.

Paradigma pembelajaran di era teknologi seperti saat ini telah berubah dari teacher centered learning menuju student centered learning. Pembelajaran di kelas diarahkan untuk menumbuhkembangkan potensi yang dimiliki peserta didik dengan guru sebagai fasilitator. Pada posisi itulah guru dituntut kreatif merancang pembelajaran dan memfasilitasi siswa dalam mendapatkan pengetahuan yang bermakna. Terlebih di era informasi digital berkembang pesat seperti saat ini, seharusnya tidak ada alasan bagi guru kekurangan informasi.
Literasi informasi seharusnya dilakukan oleh semua guru baik di kota maupun di desa, tak terkecuali guru mata pelajaran Pendidikan Agama Buddha (PAB). Literasi informasi adalah seperangkat kemampuan seseorang dalam mengetahui kapan informasi dibutuhkan, memiliki kemampuan untuk menggunakan, mengevaluasi, dan menggunakan informasi secara efektif. Literasi informasi juga diperlukan untuk meningkatkan kualitas diri dalam rangka belajar seumur hidup (Silviana, Fitriawati, dan Saepudin, 2017: 21). Berdasarkan definisidefinisi tersebut yang disebut sebagai literasi informasi dalam penelitian ini adalah kemampuan yang dimiliki oleh seorang guru untuk mengetahui kapan informasi dibutuhkan, menemukan, mengevaluasi, dan menggunakan informasi secara efektif.

Ada banyak model literasi informasi yang dikenalkan oleh para pakar. Di antara modelmodel tersebut, ada 4 model yang biasa digunakan untuk mengkaji literasi informasi dalam dunia kerja. Model tersebut antara lain The Big 6, Seven Pillars, Empowering 8, dan Information Search Process (ISP) (Septiyantono, 2010: 15-23).

Model The Big 6 diperkenalkan oleh Elsenberg dan Berko witz di tahun 1990. Keterampilan literasi informasi menurut model ini meliputi definisi tugas, strategi mencari informasi, lokasi dan akses, menggunakan informasi, sintesis, dan evaluasi. Model Seven Pillars dibuat oleh SCONUL tahun 1999 dengan keterampilan meliputi mengenal kebutuhan informasi, mengetahui sumber informasi, menentukan lokasi informasi, menentukan akses informasi, mengevaluasi informasi, mengorganisasi, dan membangun informasi baru.

Model Empowering 8 (E-8) dikenalkan tahun 2004 dengan keterampilan meliputi mengidentifikasi, mengeksplorasi, meyeleksi, mengorganisasi, mencipta, mempresentasikan, menilai, dan mengaplikasi. Sementara itu, model ISP diperkenalkan oleh Carol Kuhlthau di tahun 1989 dengan keterampilan antara lain pengenalan, seleksi, eksplorasi, koleksi, menutup pencarian, dan presentasi.

Pada dasarnya, model-model literasi informasi yang dikemukakan oleh para pakar memiliki kesamaan antara satu dengan yang lain pada beberapa tahap. Meskipun demikian, setiap model memiliki kekhasan dari sisi keterampilan yang tidak dimiliki oleh model lain. 
Suntoro, S.

LITERASI INFORMASI GURU PENDIDIKAN AGAMA BUDDHA DAN IMPLIKASINYA ...

REFLEKSI EDUKATIKA : Jurnal Ilmiah Kependidikan, Volume 9, Nomor 2, Juni 2019, hlm 182-191

Tantangan besar dalam era teknologi informasi adalah memberikan filter terhadap kemudahan akses informasi sehingga siswa tidak terjerumus dalam perilaku negatif. Hingga kini, anggapan bahwa pembentukan karakter peserta didik menjadi tugas utama bagi guru mata pelajaran pendidikan agama masih melekat. Oleh karena itu, peran dan fungsi pendidikan agama, termasuk guru $\mathrm{PAB}$ sebagai benteng pertahanan diri dari pengaruh negatif masih sangat vital. Nilai-nilai ajaran agama hingga kini dipandang ampuh untuk menangkal pengaruh negatif yang salah satunya berasal dari teknologi informasi. Tobroni (2011: 39) menyatakan guru agama hendaknya meningkatkan peran mereka dalam membentuk moral dan etika publik.

Sanaky (2015: 205) pendidikan agama di sekolah "mungkin saja" belum diorientasikan pada tataran moral actionpsikomotor, namun tidak boleh hanya berhenti pada kompetensi (competence) memahami-memiliki saja, tetapi harus sampai memiliki kemauan (will), kebiasaan (habit) dalam mewujudkan nilai dalam kehidupan sehari-hari atau "menjadi". Pada situasi itulah, peran dan fungsi guru pendidikan agama, termasuk guru PAB semakin tak tergantikan, sehingga literasi informasi menjadi tuntutan bagi guru PAB agar mampu membentengi siswa dari pengaruh negatif yang dibawa oleh teknologi informasi.

Berdasarkan data yang dihimpun dari Ketua Musyawarah Guru Mata Pelajaran (MGMP) PAB Kabupaten Pati, saat ini terdapat 23 guru yang mengajar dari tingkat SD, SMP, dan SMA yang berstatus sebagai Pegawai Negeri Sipil maupun pegawai honorer. Dari jumlah tersebut $95 \%$ di antaranya merupakan guru PAB yang termasuk dalam kelompok digital immigrant.

Istilah digital immigrant pertama kali dikemukakan oleh Mark Prensky sebagai oposisi dari istilah digital natives yang menurut Jim Marteney disebut juga internet generation. Digital immigrant adalah kita yang tidak lahir di saat dunia digital tetapi dalam perjalanan waktu tertarik dan ikut mengadopsi teknologi baru dan menggunakannya. Sementara itu digital natives merujuk pada individu yang lahir pada dunia digital, tumbuh dan memperoleh pendidikan pada tingkat sekolah dasar dengan perangkat komputer (Mardiana, 2012: 7).

Dalam dunia pendidikan Bayne dan Ross menyebut digital immigrant sebagai guru dan digital natives sebagai murid yang membawa karakteristik masing-masing. Digital natives memiliki ciri-ciri seseorang yang melakukan sesuatu dengan cara multitasking, bekerja secara pararel (berjejaring), menyukai suatu permainan yang interaktif, akses secara random, ingin segera mendapatkan informasi dalam waktu cepat, serta preferensi informasi pada sumbersumber online lebih besar dibanding sumber informasi di perpustakaan.

Ciri tersebut jelas memberi gambaran bahwa antara guru digital immigrant dan murid digital natives seperti dua kutub yang berseberangan. Ada pemisah yang tegas antara kedua generasi ini, sehingga memungkinkan terjadinya permasalahan dalam pembelajaran. Lebih lanjut André du Plessis and Paul Webb (2012: 342) menyatakan "as such there is a need for information on ways to support teachers, particularly those who are digital immigrants, to cope with the demands of the curriculum and the 21st century skills implied therein". Pendapat tersebut menekankan perlunya dukungan bagi guru digital immigrant agar mampu memahami perubahan pendidikan abad 21 .

Penelitian Shelley Kinash, Kayleen Wood, dan Diana Knight (2013) dalam penelitian yang berjudul "Digital Immigrant Teachers and Digital Native Students: What Happens to Teaching?" menjelaskan bahwa Tidak ada kesepahaman antara dosen dan mahasiswa karena para dosen tidak tumbuh di era teknologi digital, sedangkan mahasiswa tumbuh pada era tersebut. Meskipun demikian, berdasarkan penjelasan tidak terdapat kesenjangan antara teknologi yang digunakan oleh dosen dan keinginan mahasiswa.

Dalam kaitannya Pembelajaran PAB di Kabupaten Pati, penulis mencatat setidaknya ada tiga permasalahan pokok yang patut mendapat perhatian. Pertama, adanya kesenjangan generasi yang jauh antara guru dan siswa. Kedua, terbatasnya akses informasi bagi guru PAB untuk mengembangkan kompetensi. Ada beberapa indikator yang dapat dijadikan acuan untuk menggambarkan kondisi tersebut. Misalnya kesempatan guru dalam memperoleh informasi pendidikan terbaru sangat minim. Dalam kasus penerapan Kurikulum 2013 (K13) misalnya, tidak semua guru memperoleh kesempatan yang sama untuk diberikan peataran. Akibatnya guru hanya menggantungkan informasi dari rekan sejawat atau memiliki inisiatif untuk mencari 
Suntoro, S.

LITERASI INFORMASI GURU PENDIDIKAN AGAMA BUDDHA DAN IMPLIKASINYA ... REFLEKSI EDUKATIKA : Jurnal Ilmiah Kependidikan, Volume 9, Nomor 2, Juni 2019, hlm 182-191

melalui internet. Padahal menurut penelitian Nurkhan (2016: 45) model pendampingan, terbukti berhasil dan efektif dalam meningkatkan kemampuan pengelolaan penilaian bagi guru SD sasaran Kurikulum 2013, yang dibuktikan dengan peningkatkan pemahaman sebesar $23,9 \%$.

Ada kecenderungan guru pendidikan agama kurang diprioritaskan dalam hal memperoleh akses informasi dibandingkan guru kelas atau guru mata pelajaran Ujian Nasional (UN). Salah seorang guru menuturkan bahwa posisi guru agama di sekolah adalah guru kelas dua, sedangkan guru-guru untuk mapel UN adalah prioritas. Masyarakat menilai keberhasilan sekolah sebagai lembaga pendidikan adalah dari output yang bisa dilihat secara nyata yaitu nilai. Sementara itu, tugas dan fungsi guru agama termasuk PAB seolah terpinggirkan.

Kegiatan pengembangan keilmuan guru PAB yang diselenggarakan oleh Pemda Kabupaten Pati maupun Kementerian Agama sangat terbatas. Padahal, pengembangan kompetensi guru sangat berpengaruh terhadap kinerja guru (Putri dan Imaniyati, 2017: 93). Penelitian Selain itu, para guru juga mengeluhkan sulitnya mengakses informasi daring karena faktor kondisi geografis dan pengetahuan IT yang terbatas. Tak biasa dipungkiri medan Kabupaten Pati, khusunya di Kecamatan Cluwak dan Gunungwungkal memang tidak terlalu bagus untuk koneksi internet. Kemampuan guru PAB yang sebagian besar merupakan digital immigrant pun dalam hal mengakses informasi daring juga terbatas. Itulah beberapa faktor yang menyebabkan akses informasi guru-guru PAB di Kabupaten Pati tidak secepat guru-guru yang tinggal di perkotaan.

Ketiga, perhatian sekolah terhadap pembelajaran PAB masih rendah. Banyak sekolah yang belum memiliki ruang tersendiri untuk pembelajaran PAB. Pengajaran PAB di sekolah harus dilakukan di ruang perpustakaan, laboratorium, bahkan sebagian lainnya di vihara terdekat. Selain itu, sarana penunjang kegiatan belajar mengajar juga masih sangat kurang. Akibatnya pengajaran PAB di sekolah lebih bersifat tutorial alih-alih menerapkan metode pengajaran terbaru.

Berdasarkan fakta di atas menarik untuk memperbincangkan bagaimana strategi literasi guru PAB di Kabupaten Pati dalam menyikapi tuntutan perkembangan pendidikan dan teknologi kaitannya dengan pelaksanaan tugas keprofesionalan dan pengembangan profesi. Halhal apa saja yang sudah dan harus dilakukan oleh guru $\mathrm{PAB}$ agar mampu menjalankan tugas sebagai guru profesional dengan berbagai macam keterbatasan serta bagaimana implikasi literasi yang dalam pembelajaran PAB di kelas.

\section{METODE PENELITIAN}

Jenis penelitian yang digunakan adalah kualitatif deskriptif. Fokus penelitian ini adalah literasi informasi guru PAB di Kabupaten Pati serta implikasinya dalam pembelajaran. Literasi informasi mencakup proses menetapkan kebutuhan informasi, mengakses informasi, dan memanfaatkan informasi.

Subjek penelitian ini adalah guru-guru PAB di Kabupaten Pati yang mengajar di level SD, SMP, dan SMA. Teknik pengumpulan data yang digunakan adalah teknik nontes meliputi wawancara, observasi, dan studi dokumentasi. Analisis data dalam penelitian ini menggunakan model Milles \& Hubberman dilakukan dalam empat tahap yaitu pengumpulan data, reduksi data, penyajian data, dan penarikan simpulan seperti yang terdapat dalam alur berikut (Sugiyono, 2012: 91-92). Uji keabsahan data penelitian kualitatif menurut Sugiyono (2012: 131) meliputi uji kredibilitas (validitas internal), tranferabilitas (validitas eksternal), dependabilitas (reliabilitas), dan konfirmabilitas (obyektivitas).

\section{HASIL DAN PEMBAHASAN}

Proses literasi informasi guru PAB di Kabupaten Pati secara umum merupakan penggabungan model Big 6 Model, Empowering 8 , dan Seven Pillars yang mencakup penentuan kebutuhan informasi, akses informasi, dan pemanfaatan informasi.

\section{Penentuan Kebutuhan Informasi}

Proses literasi informasi yang dilakukan oleh guru PAB di Kabupaten Pati memulai tahapan literasi dengan menentukan kebutuhan informasi. Penentuan kebutuhan informasi berkaitan erat dengan tujuan literasi itu sendiri. Informasi apa yang hendak dicari dan apa fungsi informasi tersebut bagi pencari informasi. Dalam penelitian ini, literasi informasi oleh guru PAB hanya dibatasi pada literasi di bidang pendidikan. 
Suntoro, S.

LITERASI INFORMASI GURU PENDIDIKAN AGAMA BUDDHA DAN IMPLIKASINYA ... REFLEKSI EDUKATIKA : Jurnal Ilmiah Kependidikan, Volume 9, Nomor 2, Juni 2019, hlm 182-191

Berbicara mengenai penentuan kebutuhan informasi oleh guru PAB di Kabupaten Pati pasti berbicara tentang informasi apa yang dibutuhkan oleh guru PAB dan bagaimana menentukan kebutuhan informasi tersebut.

a. Kebutuhan informasi guru

Secara umum kebutuhan informasi guru PAB di Kabupaten Pati dapat diklasifikasikan menjadi dua bagian yaitu kebutuhan informasi yang berkaitan dengan peningkatan kompetensi keguruan dan kebutuhan informasi yang berkaitan dengan pengembangan karier. Kebutuhan informasi yang berkaitan dengan peningkatan kompetensi keguruan bertujuan untuk meningkatkan kompetensi sikap, sosial, pedagogik, dan profesional.

Bentuk informasi yang dibutuhkan guru dalam pegembangan kompetensi antara lain materi ajar, perangkat pembelajaran, kurikulum, media pembelajaran, metode pembelajaran, dan modul. Materi ajar merupakan informasi yang paling dibutuhkan dan dicari oleh guru PAB di Kabupaten Pati. Para guru menyadari bahwa sebagai tenaga pendidik guru memiliki kewajiban mentransfer pengetahuan dan nilai pada siswa. Oleh karena itu diperlukan wawasan dan pengetahuan yang komprehensif untuk melaksanakan tugas tersebut. Bahan ajar yang dipakai oleh guru untuk mengajar harus selalu disesuaikan dengan perkembangan ilmu pengetahuan.

Perubahan Kurikulum Tingkat Satuan Pendidikan (KTSP) menjadi K13 juga menjadi perhatian guru-guru PAB di Kabupaten Pati. Banyak guru yang belum memahami secara utuh mengenai K13 pada tataran perencanaan, pelaksanaan, evaluasi, hingga administrasi. Model penelusuran informasi melalui internet pun tidak banyak memberikan hasil. Hal itu disebabkan belum banyak informasi mengenai K13 yang berhubungan dengan pembelajaran PAB yang bisa diakses. Akibatnya, informasi yang didapatkan guru dari aktivitas mengakses informasi melalui internet juga sangat terbatas.

Kondisi tersebut diperparah dengan minimnya kesempatan mengikuti penataran, bintek, atau workshop yang bisa memberikan pemahaman mengenai K13. Penunjukan bagi guru PAB yang mengikuti penataran K13 dilakukan oleh Kantor Wilayah Bimbingan Masyarakat Buddha Kementerian Agama Provinsi Jawa Tengah. Kuota yang terbatas dalam setiap kegiatan penataran menyebabkan belum semua guru PAB di Kabupetan Pati menjadi peserta. Kegiatan penataran mengenai K13 yang dilakukan oleh Pemerintah Kabupaten Pati pun sangat terbatas. Sekolah pun tidak memiliki wewenang untuk menentukan peserta karena ditunjuk langsung oleh pemerintah daerah. Padahal prioritas peserta penataran K13 di Kabupaten Pati untuk tingkat SD adalah guru kelas.

Para guru PAB di Kabupaten Pati juga kesulitan mendapatkan buku ajar dan buku pegangan guru untuk K13. Hal ini berlaku baik di tingkat SD, SMP, maupun SMA. Berbagai cara telah dilakukan oleh guru seperti menghubungi Direktorat Jenderal Bimbingan Masyarakat Buddha dan menghubungi dinas pendidikan terkait namun belum ada hasilnya. Kondisi tersebut biasa disiasati guru dengan membawa permasalahan pada forum Kelompok Kerja Guru (KKG) maupun MGMP.

Penerapan K13 juga membuat guru PAB harus menyesuaikan administrasi pembelajaran. Banyak guru yang membutuhkan informasi mengenai format program tahunan (prota), program semester (promes), silabus, dan Rencana Pelaksanaan Pembelajaran (RPP). Di antara perangkat pembelajaran tersebut, yang menjadi perhatian khusus adalah RPP K13 yang telah menerapkan pendekatan saintifik meliputi kegiatan mengamati, menanya, menalar, mengasosiasi, dan mempresentasikan. Untuk menyiasati hal itu, para guru bersepakat secara bersama membuat RPP K13 untuk semua jenjang pada forum $\mathrm{KKG}$.

Selain hal-hal di atas, informasi lain yang dibutuhkan oleh guru PAB untuk meningkatkan kompetensi adalah mengenai metode pembelajaran dan media pembelajaran. Meskipun guru PAB di Kabupaten Pati rata-rata berusia tua, namun dalam hal pemanfaatan teknologi sebagai media pembelajaran terbilang bagus. Meskipun tidak menguasai teknologi informasi namun keterampilan minimal pemanfaatan media dalam pembelajaran sudah dikuasai. Namun, jumlah murid yang sedikit membuat guru harus mencari informasi mengenai metode pembelajaran yang efektif untuk diterapkan.

Bentuk kebutuhan informasi yang digunakan guru dalam pengembangan karier seperti produk hukum yang mengatur sertifikasi guru dan kenaikan pangkat bagi seorang guru. Guru harus selalu memperbarui informasi 
Suntoro, S.

LITERASI INFORMASI GURU PENDIDIKAN AGAMA BUDDHA DAN IMPLIKASINYA ... REFLEKSI EDUKATIKA : Jurnal Ilmiah Kependidikan, Volume 9, Nomor 2, Juni 2019, hlm 182-191

mengenai peraturan-peraturan pendidikan agar tidak menyimpang dari norma yang berlaku. Meskipun guru-guru PAB di Kabupaten Pati telah berusia senja (digital immigrant) namum dari sisi kepangkatan masih di golongan III. Hal ini disebabkan oleh tuntutan membuat Penelitian Tindakan Kelas (PTK) agar bisa naik pangkat. Syarat tersebut bagi sebagian besar guru dianggap terlalu memberatkan, sehingga banyak guru yang tidak mengacuhkan.

b. Cara menentukan kebutuhan informasi Para guru PAB di Kabupaten Pati sepenuhnya menyadari tugas dan fungsinya sebagai guru. Memperbarui dan menambah pengetahuan atau informasi sudah menjadi kebutuhan sehari-hari. Para guru menyadari bahwa tugas guru PAB bukan hanya mentransfer pengetahuan tetapi yang lebih penting adalah mentransfer nilai-nilai Buddha Dhamma agar bisa dipraktikkan siswa dalam kehidupan seharihari.

Ada dua cara yang digunakan oleh guru dalam menentukan kebutuhan informasi berdasarkan tingkat kepentingganya. Informasi yang berhubungan dengan peningkatan kompetensi dan pembelajaran merupakan kewajiban sehari-hari. Sementara itu, informasi pendidikan di luar untuk dua hal tersebut merupakan kebutuhan yang sifatnya insidental.

Berdasarkan penggolongan di atas dapat kita simpulkan bahwa para guru telah mampu menetapkan skala prioritas kebutuhan informasi secara tepat. Implikasi dari hal tersebut adalah kewajiban bagi guru untuk merencanakan, melaksanakan, dan mengevaluasi pembelajaran dengan penuh kesadaran dan tanggung jawab. Hal itu tentu berdampak pada kualitas pembelajaran PAB di sekolah.

\footnotetext{
Akses Informasi

Akses informasi merupakan kegiatan menentukan lokasi informasi, menyusun strategi penelusuran informasi, menganalisis dan mengorganisasi informasi, menyimpan informasi, serta mengevaluasi informasi. Dalam mengakses informasi tentu tidak selalu berjalan mulus, ada kalanya juga menemui kendala baik teknis maupun nonteknis. Berikut penjelasan lengkap mengenai akses informasi pendidikan yang dilakukan oleh guru PAB di Kabupaten Pati.
}

a. Lokasi

Ada banyak lokasi yang digunakan oleh guru PAB di Kabupaten Pati untuk mengakses informasi. Di antara banyak lokasi penelusuran, internet merupakan yang paling favorit. Selain internet, para guru biasa mengakses informasi melalui buku, MGMP, KKG, bintek, penataran, teman sebaya, grup whatsapp, dan majalah. Melihat fakta tersebut artinya para guru telah mampu memanfaatkan banyak saluran informasi untuk menjadi guru yang profesional.

Internet menjadi favorit guru dalam mengakses informasi karena kemudahan dan efektivitasnya. Setiap informasi dapat didapatkan dengan mudah hanya dengan mengetikkan kata kunci. Dari setiap penelusuran para guru bisa mendapatkan informasi yang banyak dalam waktu yang singkat. Tentu hal ini berbeda ketika menelusuri informasi lewat buku. Namun, diakui oleh guru bahwa preferensi terhadap internet tidak bisa dilepaskan dari ketiadaan buku untuk mengajarkan K13.

Buku Pelajaran PAB merupakan andalan guru dalam pelaksanaan kegiatan belajar mengajar di kelas. Jika pada saat penerapan KTSP semua guru memiliki buku pelajaran PAB, kondisi berbeda dialami guru saat penerapan K13. Para guru kesulitan mendapatkan buku pelajaran PAB. Itulah yang menyebabkan intensitas guru dalam mengakses informasi dari buku pelajaran terbatas. Bahkan, hingga kini masih banyak guru yang mengajar menggunakan buku pelajaran KTSP untuk mengajarkan materi yang memiliki kesamaan.

Forum KKG maupun MGMP juga menjadi wadah yang efektif bagi guru untuk mengakses informasi. Jika guru mengalami kebuntuan terhadap persoalan dalam dunia pendidikan, KKG merupakan alternatif pemecahannya. Melalui forum tersebut para guru dapat bertukar pikiran, ide, dan pengetahuan. Permasalahan yang tidak bisa dijawab melalui akses informasi dari internet maupun dari buku, dibawa ke forum $\mathrm{KKG}$ untuk dicarikan solusi bersama.

Kegiatan KKG PAB di Kabupaten Pati dilaksanakan setiap dua minggu sekali secara bergilir. Pelaksanaan KKG dilakukan secara bergantian di vihara-vihara yang ada di Kecamatan Cluwak, Gunungwungkal, dan Juwana. Bahasan utama KKG adalah seputar pembelajaran PAB di sekolah. Misalnya, guru yang selesai penataran wajib membagikan 
Suntoro, S.

LITERASI INFORMASI GURU PENDIDIKAN AGAMA BUDDHA DAN IMPLIKASINYA ...

REFLEKSI EDUKATIKA : Jurnal Ilmiah Kependidikan, Volume 9, Nomor 2, Juni 2019, hlm 182-191

pengalamannya dalam forum tersebut. Dalam forum tersebut para guru juga mengadakan workshop pembuatan perangkat pembelajaran K13.

Para guru juga mendapatkan informasi melalui kegiatan workshop, bintek, atau penataran yang diselenggarakan oleh Pemda, Kanwil Kemenag Jateng, dan Sekolah Tinggi Agama Buddha (STAB). Materi penataran bervariasi mulai dari implementasi K13, perangkat pembelajaran, hingga Penelitian Tindakan Kelas (PTK). Kegiatan-kegiatan seperti di atas sangat membantu guru-guru PAB yang ada di daerah agar tidak ketinggalan informasi.

Meskipun tinggal di pedesaan dan sebagian besar telah berusia senja, namun dalam hal pemanfaatan TIK guru PAB di Kabupaten Pati terbilang cakap. Bahkan guru-guru tersebut memiliki grup whatsapp yang digunakan untuk berbagi informasi. Meskipun tidak selalu berisi informasi pendidikan, keberadaan grup tersebut sangat membantu khususnya dalam hal update informasi terbaru bagi guru. Whatsapp juga menjadi media yang efektif untuk berkomunikasi dengan sesama guru PAB di Kabupaten Pati.

Saluran terakhir yang biasa digunakan guru untuk mengakses informasi adalah majalah. Majalah yang dimaksud adalah majalah-majalah yang berisi artikel dan gambar-gambar Buddhis yang dapat digunakan oleh guru sebagai bahan ajar atau media pembelajaran di kelas. Akses informasi dari majalah juga bertujuan untuk meningkatkan pengetahuan guru. Para guru biasa mendapatkan majalah di vihara-vihara atau pada saat mengikuti kegiatan.

b. Strategi penelusuran

Strategi penelusuran informasi berkaitan dengan penetapan skala prioritas lokasi dalam mengakses setiap jenis informasi yang berbeda. Guru PAB di Kabupaten Pati menerapkan strategi penelusuran yang berbeda untuk setiap tujuan dan jenis informasi yang berbeda. Misalnya untuk tujuan mencari bahan ajar, buku dan internet adalah skala prioritas lokasi yang digunakan. Sementara itu untuk informasi yang berhubungan dengan pengembangan karier, forum guru adalah lokasi yang tepat untuk mendapatkan informasi.

Namun pada umumnya setiap guru menempatkan internet dan buku sebagai prioritas dalam literasi informasi. Sumber lain seperti forum guru, teman sejawat, majalah, maupun grup whatsapp adalah preferensi berikutnya. Meskipun tidak didukung dengan kemampuan penguasaan teknologi informasi yang andal, guru PAB menyadari kemudahan yang ditawarkan oleh internet sangat luar biasa. Itulah yang membuat internet menjadi rujukan yang sering digunakan guru sebagai modal menyiapkan bahan ajar atau menggali informasi baru dalam dunia pendidikan.

c. Analisis dan organisasi

Informasi yang didapatkan oleh guru dari berbagai macam sumber dianalisis terlebih dahulu. Guru PAB di Kabupaten Pati telah mengetahui bahwa tidak semua informasi yang didapatkan merupakan informasi yang baik. Terlebih informasi itu berasal dari internet, banyak sekali informasi sampah. Oleh karena itu, sebelum menggunakan informasi tersebut guru telah terbiasa melakukan analisis informasi. Informasi sampah (hoax) jika digunakan dalam KBM akan merugikan siswa.

Informasi yang telah terkumpul kemudian diorganisasi sebelum dimanfaatkan oleh guru untuk menambah wawasan maupun untuk keperluan KBM. Para guru terbiasa memadukan informasi yang didapatkan dari berbagai sumber agar diperoleh informasi yang kredibel dan komprehensif. Terkadang, untuk kebutuhan KBM para guru harus menyarikan informasi dari sumber yang berbeda-beda karena keterbatasan informasi.

d. Penyimpanan

Akses informasi bertujuan untuk menambah wawasan dan meningkatkan pengetahuan. Informasi yang didapatkan oleh guru sebagian disimpan sebagian lainnya hanya dibaca saja. Penyimpanan informasi selalu memiliki tujuan baik jangka pendek maupun jangka panjang. Informasi yang disimpan oleh guru PAB biasanya memiliki sifat penting bagi pelaksanaan tugas mengajar maupun peningkatan karier guru tersebut.

Dalam hal penyimpanan informasi, guru biasa memanfaatkan perangkat komputer, laptop, $\mathrm{hp}$, dan flashdisk. Ada juga yang informasi yang setelah diakses kemudian dicetak. Guru yang preventif menggabungkan dua model penyimpanan informasi yaitu menyimpan file dalam perangkat sekaligur mencetak file tersebut. Hal itu untuk menghindari kemungkinan file rusak, terkena virus, atau dokumen yang dicetak hilang atau rusak. 
Suntoro, S.

LITERASI INFORMASI GURU PENDIDIKAN AGAMA BUDDHA DAN IMPLIKASINYA ... REFLEKSI EDUKATIKA : Jurnal Ilmiah Kependidikan, Volume 9, Nomor 2, Juni 2019, hlm 182-191

Ada hal yang menarik melihat temuan di atas bahwa guru PAB di Kabupaten Pati sangat akrab dengan teknologi. Hampir setiap guru memiliki laptop pribadi dan mampu mengoperasikannya dengan cukup baik. Meskipun demikian, para guru menyadari bahwa kemampuan di bidang teknologi masih kurang sehingga perlu banyak belajar.

e. Kendala

Ada beberapa kendala akses informasi yang dilakukan oleh guru-guru PAB di Kabupaten Pati. Pertama, untuk akses informasi dari internet koneksi jaringan tidak terlalu baik sehingga berpengaruh terhadap produktivitas perolehan informasi. Jika melihat kondisi geografis Kabupaten Pati khusunya Kecamatan Cluwak dan Gunungwungkal kondisi medannya berbukit-bukit. Tidak semua provider bisa digunakan untuk akses internet. Beberapa yang bisa kekuatan signal dan koneksinya juga tidak terlalu bagus.

Beberapa guru lebih suka mengakses internet di sekolah. Selain koneksi bagus juga dapat saling belajar dengan teman sejawat. Beberapa guru bahkan memasang perangkat wifi di rumah agar mendapatkan koneksi internet yang bagus. Listrik juga sering mati akibat pemadaman bergilir maupun kondisi alam. Salah seorang guru menuturkan bahwa pada saat hujan deras dan angin kencang, peluang PLN mematikan listrik sangat besar untuk keselamatan warga. Hal itu dikeluhkan oleh guru karena dapat mengganggu akses informasi.

Kedua, keterbatasan sumber informasi khususnya buku pelajaran PAB. Belum tersedianya buku pelajaran $\mathrm{PAB}$ untuk jenjang SD, SMP, SMA merupakan tantangan bagi guru. Guru harus memutar otak untuk menyiasati kondisi tersebut mengingat buku pelajaran merupakan acuan utama dalam proses pembelajaran, misalnya mengakses dari internet. Oleh karena itu, forum guru seperti KKG dan MGMP merupakan pilihan terakhir jika informasi yang dibutuhkan tidak berhasil didapat.

Ketiga, forum guru PAB untuk level SMP dan SMA dilaksanakan secara gabungan. Terbatasnya jumlah guru PAB pada jenjang SMP dan SMA membuat forum MGMP PAB Kabupaten Pati digabung dengan Kabupaten Jepara dan Kudus. Forum itu tidak efektif seperti halnya MGMP PAB Kabupaten Pati untuk tingkat SD karena jarak yang relatif jauh. Jika dilaksanakan di luar Kabupaten Pati, peluang guru untuk hadir dalam forum tersebut sangat kecil. Hal ini mengakibatkan sharing informasi dan pengetahuan guru PAB untuk jenjang SMP dan SMA terbatas pada beberapa orang saja.

\section{f. Evaluasi}

Evaluasi merupakan langkah terakhir dalam kegiatan literasi informasi menurut The Big6 Model. Evaluasi literasi informasi dapat didasarkan pada dua hal yaitu strategi penelusuran (efektivitas) dan perolehan informasi (produktivitas). Strategi penelusuran berhubungan dengan seberapa efektif seseorang mengakses informasi, sedangkan perolehan informasi merujuk pada produktivitas dan kualitas informasi yang didapatkan.

Evaluasi terhadap strategi penelusuran informasi dilakukan guru dengan cara mengubah akses ke lokasi informasi atau mengganti cara penelusuran dalam lokasi tersebut. Mengubah akses lokasi informasi artinya jika guru tidak mendapatkan informasi dari website dan buku maka untuk informasi serupa guru akan berpindah lokasi penelusuran misalnya teman sebaya atau forum guru. Mengganti cara penelusuran informasi biasa digunakan jika akses informasi dilakukan melalui internet. Guru terbiasa mengganti keyword atau kata kunci untuk memperoleh informasi yang lebih komprehensif.

Guru juga mampu mengevaluasi perolehan informasi dari proses literasi informasi. Guru bisa menilai dan memilah informasi yang sesuai tujuan dan dapar dipertanggungjawabkan kebenarannya. Seleksi informasi yang sering dilakukan guru adalah terhadap materi pembelajaran yang akan diajarkan kepada siswa. Guru PAB menyadari bahwa materi ajar yang baik akan mengondisikan pembelajaran lebih bermakna.

\section{Pemanfaatan Informasi}

Menurut Model Seven Pillars, model literasi informasi diakhiri dengan tahap menciptakan informasi baru. Berdasarkan informasi yang didapat dari bermacam sumber, seseorang harus mampu menciptakan pengetahuan dan informasinya sendiri. Bentuk penciptaan informasi yang dilakukan oleh guru PAB di Kabupaten Pati adalah memanfaatkan informasi yang diperoleh sebagai bahan ajar di sekolah. 
Suntoro, S.

LITERASI INFORMASI GURU PENDIDIKAN AGAMA BUDDHA DAN IMPLIKASINYA ... REFLEKSI EDUKATIKA : Jurnal Ilmiah Kependidikan, Volume 9, Nomor 2, Juni 2019, hlm 182-191

a. Pemanfaatan dalam pembelajaran

Bentuk informasi yang dipakai oleh guru dalam kegiatan belajar mengajar antara lain materi ajar, video, dan gambar. Materi ajar K13 adalah informasi yang sering dicari untuk kemudian digunakan guru dalam pembelajaran. Selain materi, umumnya guru mencari media pembelajaran yang dapat meningkatkan motivasi siswa untuk belajar. Jumlah siswa yang relatif sedikit membuat guru harus memilih strategi pembelajaran dan media yang tepat untuk membangkitkan minat belajar siswa.

Di antara banyak media, gambar dan video merupakan media yang paling sering digunakan guru dalam pembelajaran. Tentu media pembelajaran tersebut disesuaikan dengan materi yang diajarkan. Gambar dan video biasa ditunjukkan oleh guru melalui laptop pribadi. Hal itu dikarenakan tidak tersedia fasilitas projector dalam ruang pembelajaran $\mathrm{PAB}$.

Video yang biasa diputar oleh guru adalah video riwayat Buddha Gotama dan video ceramah bhikku yang dapat diunduh secara gratis di internet. Penggunaan media pembelajaran seperti video mendapat respon yang positif dari siswa. Siswa merasa sangat senang karena merasa melihat langsung objek yang sedang dipelajari. Selain itu, bagi siswa yang tinggal di desa penggunaan media dalam pembelajaran masih sangat awam.

b. Kendala

Kendala pemanfaatan informasi sebagai sumber belajar dan media belajar bagi siswa secara umum adalah ketersediaan sarana dan prasarana pembelajaran. Belum semua sekolah memiliki ruang belajar untuk pembelajaran PAB. Kegiatan pembelajaran PAB dilakukan di perpustakaan, laboratorium, ruang kepala sekolah, atau vihara terdekat dengan sekolah. Bahkan, pembelajaran PAB di beebrapa sekolah dilakukan secara nomaden karena tidak tersedia ruang permanen. Dalam kondisi tersebut para guru selalu memberikan pengertian kepada siswa agar tidak timbul rasa iri hati dengan teman yang berbeda agama.

Beberapa sekolah yang telah memiliki ruang $\mathrm{KBM}$ mandiri juga terkendala dengan ketiadaan projector sebagai alat bantu pengajaran. Meskipun keberadaan projector oleh para guru dianggap sangat penting, namun mereka menyadari kondisi sekolah yang belum memungkinkan untuk menyediakan sarana tersebut. Para guru khususnya di SMP dan SMA juga menegeluhkan perhatian pihak sekolah terhadap siswa beragama Buddha. Guru berharap siswa beragama Buddha memiliki kesempatan dan hak yang sama dalam memperoleh layanan pendidikan di sekolah.

Kendala terakhir dalam pemanfaatan informasi di sekolah adalah jumlah siswa yang tidak terlalu banyak. Ada guru yang mengungkapkan dengan kondisi tersebut mustahil untuk menggunakan metode pembelajaran secara berkelompok yang sering dipelajari saat penataran atau didapatkan dari buku dan internet. Pengajaran PAB di sekolah saat ini dilaksanakan seperti tutorial.

\section{SIMPULAN}

Kebutuhan informasi guru PAB di Kabupaten Pati secara umum terbagi menjadi dua yaitu informasi untuk peningkatan kompetensi guru dan pengembangan karier. Guru PAB di Kabupaten Pati menggunakan beragam akses dalam menggali informasi seperti internet, buku, forum KKG dan MGMP, bintek, penataran guru, teman sebaya, majalah, serta grup whatsapp. Setiap informasi yang didapatkan oleh guru dari berbagai sumber telah dianalisis dan diorganisasi dengan baik. Para guru juga telah mampu menyimpan setiap perolehan informasi dengan menggunakan laptop, flashdisk, print out, handphone atau sekadar dibaca. Guru juga mengevaluasi literasi informasi yang dilakukan baik dari strategi penelusuran (efektifivitas) maupun perolehan informasi (produktivitas). Sementara itu, kendala dalam literasi informasi antara lain lemahnya koneksi internet, sering terjadi pemadaman listrik, buku K13 belum tersedia, dan forum guru untuk tingkat SMP dan SMA yang tergabung dengan kabupaten lain.

Bentuk penciptaan informasi yang dilakukan oleh guru PAB di Kabupaten Pati adalah memanfaatkan informasi yang diperoleh sebagai bahan ajar di sekolah. Bentuk informasi yang digunakan dalam pembelajaran antara lain materi ajar, video, dan gambar. Respon siswa sangat baik dengan pemanfaatan informasi sebagai media dan sumber belajar. Namun dalam pemanfaatan informasi guru mengalami kendala antara lain ketersediaan sarana dan prasarana di sekolah masih sangat minim, jumlah murid yang sedikit, serta rendahnya perhatian pihak sekolah bagi pembelajaran $\mathrm{PAB}$. 
Suntoro, S.

LITERASI INFORMASI GURU PENDIDIKAN AGAMA BUDDHA DAN IMPLIKASINYA ...

REFLEKSI EDUKATIKA : Jurnal Ilmiah Kependidikan, Volume 9, Nomor 2, Juni 2019, hlm 182-191

\section{DAFTAR PUSTAKA}

André du Plessis and Paul Webb. 2012. Digital Immigrant Teacher Perceptions of An Extended Cyberhunt Strategy. Australasian Journal of Educational Technology. Volume 28 (2): 341-363.

Hujair A. H. Sanaky. 2015. Pembaruan Pendidikan Islam, Paradigma, Tipologi, dan Pemetaan Menuju Masyarakat Madani Indonesia. Yogyakarta: Kaukaba Dipantara.

Mardiana, Riana. 2012. Potensi Digital Natives dalam Representasi Literasi Informasi Multimedia Berbasis Web Di Perguruan Tinggi. Jurnal Pustakawan Indonesia, 11 (1): 1-13.

Moleong, Lexy J. 2012. Metodologi Penelitian Kualitatif. Bandung: PT Remaja. Rosdakarya.

Nurhkan. 2016. Peningkatan Kemampuan Pengelolaan Penilaian Kurikulum 2013 Melalui Pendampingan bagi Guru Sekolah Dasar. Jurnal Refleksi Edukatika, 7 (1): 45-55.
Peraturan Pemerintah No 19 tahun 2005 tentang Standar Nasional Pendidikan.

Putri, A. D. K., dan Nani Imaniyati. 2017. Pengembangan Profesi Guru dalam Meningkatkan Kinerja Guru. Jurnal Pendidikan Manajemen Perkantoran, 2 (2): 93-101.

Septiyantono, Tri. 2010. Literasi Informasi. Jakarta: Universiitas Terbuka Press.

Shelley K., Kayleen Wood, dan Diana Knight. 2013. Digital Immigrant Teachers and Digital Native Students: What Happens to Teaching?: Epublication Bond University.

Silviana, T., Fitriawati, Encang Saepudin. 2017. Studi tentang Literasi Informasi di Kalangan Siswa Menengah Pertama. Edulib, 7 (7): 17-28.

Sugiyono. 2009. Metode Penelitian Kuantitatif, Kualitatif, dan R\&D. Bandung: Alfabeta.

Tobroni. 2011. Peranan Pendidikan Agama dalam Pembentukan Etika Sosial Persaudaraan dan Perdamaian. Jurnal PROGRESIVA 5, (1): 39-54. 